\title{
SWOT ANALYSIS OF PLANT HEALTH CLINICS AS PERCEIVED BY PLANT DOCTORS IN NEPAL
}

\author{
R. K. Adhikari ${ }^{1}$, P. P. Regmi ${ }^{1}$, R. B. Thapa ${ }^{1}$, Y. D. G.C. ${ }^{2}$ and E. Boa ${ }^{3}$ \\ ${ }^{1}$ Institute of Agriculture and Animal Sciences, Tribhuvan University, Nepal, ${ }^{2}$ Department of \\ Agriculture/Government of Nepal, ${ }^{3}$ University of Aberdeen, UK.
}

\begin{abstract}
This paper identified and examined the internal and external forces that enable or inhibit the performance of plant clinics in Nepal. The study used web-based online survey tool to collect primary information. Likert scaling and indexing techniques were used on data analysis. Pretested set of questionnaires were mailed to 209 plant doctors and the response rate was $54.54 \%$. Being ninth country to initiate plant health clinics, Nepal is successful to adapt this novel approach into the existing extension system. It has increased access to plant health services by providing wide range of services at a place. However,limited understanding and only profit motive of local private agro-vet and input dealers has created some biased-understanding and un-trust with clinic organizers. This SWOT analysis clearly spells the scope of plant clinics to fulfill the gap between farmers need and existing services provided by public extension system.
\end{abstract}

Key Words: SWOT, Plant clinic, Extension, Plant doctor, healthcare

\section{INTRODUCTION}

Agricultural professionals play role in identifying, adapting and sharing technology that is appropriate to the needs of farmers within diverse natural and social contexts (Landon, 1996) to make new knowledge available to farmers and assist the farmers to develop their farming and management skill (Chipeta, 2006; Purcell \& Anderson, 1997) to increase agriculture production, productivity and sustainability of their agriculture production system with an objective of improving livelihood standard. Improved agricultural production coupled with protection of the natural resource base is the key element to reduce the poverty and malnutrition in rural areas (Anandajayasekeram, Davis, \& Workneh, 2007) where agriculture extension has long been proven tool for enabling farmers to obtain information and technologies and ultimately improve their livelihoods (Purcell \& Anderson, 1997). According to a survey by FAO, about $81 \%$ of extension work around the world is carried out through Government (Umali \& Schwartz, 1994). In Nepal, institutionalized agricultural extension from public sector only started in 1950s (K.C., Pradhan, Upadhyay, \& Upadhyay, 2003) but for many years, it remained focused on just a few crops and technologies where research, input supply and regulatory services remained disconnected. After several changes in public agricultural extension system, the District Agriculture Development Office (DADO) and the Agricultural Service Center (ASC) are the responsible authorities to provide agricultural extension services including the plant health care. Available data (DoAE, 2011) shows the ratio of public extension staff to farm household is 1:164 (Adhikari, Regmi, Boa, GC, \& Thapa, 2013) which clearly indicates the no or poor access to agriculture extension services for majority of smallholder farmers in Nepal. The limited number of agricultural extension staffs either from government or non-government sectors is one of the critical factors to provide efficient and effective agricultural extension services.

Diseases, insects, weeds and other pests annually cause substantial losses in the yield and quality of agriculture produce. According to (Oerke, 2006) different pests are responsible for 26 
to $40 \%$ of the potential yields in major food and cash crops worldwide. Sometimes losses are even greater, especially when post-harvest losses are considered. Much harvested food is contaminated with mycotoxins, pesticides, and pathogens, making it unfit for human consumption (European Commission, 2005; Kroschel, Alcazar, \& Poma, 2009). Therefore, access to agricultural extension services including sound plant health extension services is very important factor for increased productivity and thus accelerated agricultural growth and ultimately the food security.

Due to limited access to agricultural extension services, the knowledge about plant health issues among smallholder farmers is very poor resulting inappropriate use of pesticides (Atreya, 2005) which could have hazardous impact on human being, livestock and environment (Shrestha \& Neupane, 2002). Therefore, it is important to provide appropriate plant health service that provide adequate advisory facility to the farmers on their plant health problems along with preventive and curative measures.Moreover, these services should be available at the time of farmers' need. To overcome some of the gaps of plant health extension the concept of 'plant health clinic' also called 'plant clinic' has been evolved as a novel approach in providing regular, low-cost plant health services to farmers since 2003 (Bentley et al., 2009; Bentley, Boa, Almendras, Franco, Antezana, Diaz, et al., 2011; Bentley, Boa, Danielsen, \& Zakaria, 2007; Boa, 2009). Similar as the concept of clinic for human and animals, plant clinic provides primary health care for plants (Danielsen \& Kelly, 2010) which are run by local extension workers at any places that are convenient to famers of the area and are equipped with very simple tools and facilities to examine the sick plants brought by the farmers (Bentley et al., 2007; Danielsen \& Kelly, 2010).

This was first piloted in Bolivia (Bentley \& Boa, 2004) and gradually replicated in more than 16 countries, (Plantwise, 2011). In Nepal, the first clinic was piloted in Lamjung during 2008 (Boa \& Harling, 2008) and gradually replicated in other districts by different NGOs. Now, this concept has been mainstreamed into government's extension system where DADO and PPD are running clinics in different districts.

\section{METHODOLOGY}

The origin of SWOT was SOFT (Satisfactory, Opportunity, Fault and Threat) which was first presented in a seminar at Zurich in 1964 where Fault (F) was changed into Weakness (W) and then called as SWOT (Humphrey, 2005). Subsequently, Weihrich (1982) modified SWOT in the format of a matrix, matching the internal factors of an organization with its external factors to systematically generate strategies. The SWOT analysis is a tool for strategic analysis that deals with an overview of the internal and external environment for any business or initiative in achieving their objective (Hanyani-Mlambo, 2002). SWOT is a simple but useful framework for analyzing the organization's strengths and weaknesses, and the opportunities and threats that the organization faces. Perhaps it is the most well-known approach for drafting strategy (Zack, 1999) by analyzing the internal capabilities in relation to competitive environment (Avison \& Fitzgerald, 2006) that helps to focus on your strengths, minimize threats, and take the greatest possible advantage of opportunities available. SWOT analysis tool has been used by different researchers to assess the strength, weakness, opportunities and threats of the agricultural extension system (Alonge, 2006; Hanyani-Mlambo, 2002; Oerke, 2006; Piggin, 2003; Shahraki \& Ebrahimzadeh, 2013). Similarly, FAO adopted this tool in 2010 to prepare Nepal's National Mid Term Priority Framework for agriculture and livestock extension (Thapa, 2010). 


\begin{tabular}{|c|c|c|}
\hline $\begin{array}{l}\text { PERFORMANCE } \\
\text { FACTORS }\end{array}$ & Enhancers & Inhibitors \\
\hline Internal & 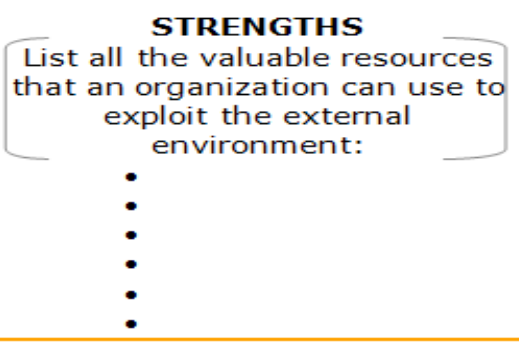 & $\begin{array}{l}\text { WEAKNESSES } \\
\text { List all the resources that an } \\
\text { organization requires to perform in } \\
\text { the external environment: } \\
\text { :- } \\
\text { - }\end{array}$ \\
\hline External & $\begin{array}{l}\text { OPPORTUNITIES } \\
\text { List all the possibilities that an } \\
\text { organization can pursue or } \\
\text { exploit to gain benefit: } \\
\text { : } \\
\text { : } \\
\text { - }\end{array}$ & $\begin{array}{l}\text { THREATS } \\
\text { List all the factors that have the } \\
\text { potential to reduce an } \\
\text { organization's performance: } \\
\text { - } \\
\text { - }\end{array}$ \\
\hline
\end{tabular}

Figure1: Framework of SWOT analysis

In response to the difficulty of measuring character and personality traits, Likert, (1932) developed a procedure for measuring attitudinal scales which is later termed as Likert Scale. In this scale, series of questions with five alternatives are asked to the individuals and composite score is derived to measure. Now, this Likert scaling technique is being widely used by extension professionals with wider variation in number of options (Boone \& Boone, 2012). This this research too, the questions were structured on 5 point Likert type rating scales (1-5) and the perceived importance each of the factors can be rated collectively on a Likert scale of 1-5. The composite index of importance of each statement is computed by using formula below

$$
I=\sum \frac{F i X i}{N}
$$

Where,

$\mathrm{I}=$ Index of Importance

$\mathrm{Fi}=$ frequency of $\mathrm{i}^{\text {th }}$ variable

$\mathrm{Xi}=$ relative weight of $\mathrm{i}^{\text {th }}$ variable

$\mathrm{N}=$ total number of respondents

This study has been carried out based on response of plant doctors. A set of statements on strength, weakness, opportunity and threat were listed through reviewing published and unpublished documents of different organizations, personal consultation with plant doctors and related stakeholders. Thus prepared statements were validated through consultation with experts on agricultural extension and senior researchers. In addition, the set of question and statement was tested and validated through six focus group discussions. This study has used kwiksurvey online survey tool (www.kwiksurvey. $\underline{\text { com) }}$ to collect the primary information. After creating a user account, the finalized questionnaire is 
uploaded in the website and the web-link was mailed to the plant doctor's email address requesting to complete the survey within a month.

The population of this study consisted of plant doctors who have been trained through special package 'how to become a plant doctor?' A list of 257 plant doctors was prepared through consulting the training organizers but 41 of them do not have access to email/internet. Therefore the survey web link was mailed to 216 individual. But it couldn't reach to 7 recipients due to error in email address. Thus total study population became only 209 . Out of them, 114 (54.5\% response rate) recipients participated in the survey.

Basic statistical analysis was done directly in kwiksurvey while some of the complex data were exported into excel format for re-tabulation. Thus collected data were through Statistical Package for Social Sciences (SPSS).

\section{Agricultural extension and Plant Clinics in Nepal}

\section{RESULTS AND DISCUSSION}

In the 1950s institutionalized extension services began in Nepal with support from donors and the government (DoAE, 2011; K.C. et al., 2003). Planned agricultural development started in 1952 with the creation of the Tribhuvan Village Development Department which introduced the block development approach in extension. Several approaches were introduced in different plan periods. Some of the key milestones of agriculture extension are presented in table 1.

Table 1. Evolution of agricultural extension in Nepal

\begin{tabular}{|c|c|}
\hline Date & Key Development in Extension \\
\hline 1951 & Institutionalization of extension service began \\
\hline 1952 & $\begin{array}{l}\text { Tribhuvan Village Development Department established and block development } \\
\text { approach introduced }\end{array}$ \\
\hline 1955 & $\begin{array}{l}\text { Department of Agriculture was created. Extension division with zonal extension } \\
\text { offices established }\end{array}$ \\
\hline 1968 & $\begin{array}{l}\text { Gandaki Agricultural Development Project (1968-78), fertilizer-based Green } \\
\text { Revolution type extension approach }\end{array}$ \\
\hline Mid 70s & $\begin{array}{l}\text { Integrated Hill Development Project (IHDP) and Integrated Rural Development } \\
\text { Project (IRDP) - high input technology based-extension }\end{array}$ \\
\hline 1975 & $\begin{array}{l}\text { Training and Visit (T\&V) approach introduced in Narayani Zone Irrigation } \\
\text { Development Project (NZIDP) }\end{array}$ \\
\hline 1978 & $\begin{array}{l}\text { DoA formed in } 1972 \text { was split into Department of Agriculture and Department of } \\
\text { Livestock Development and Animal Health }\end{array}$ \\
\hline $1980 s-1990 s$ & $\begin{array}{l}\text { Third Livestock Development Project (TLDP) \& Hill Agriculture Research Project } \\
\text { (HARP) had modernized agriculture extension systems }\end{array}$ \\
\hline 1991 & $\begin{array}{l}\text { All extension services were brought under one umbrella organization in the Department } \\
\text { of Agricultural Development }\end{array}$ \\
\hline 2008 & Concept of Plant Clinic was introduced \\
\hline 2011 & $\begin{array}{l}\text { Government of Nepal formally adopted plant clinic approach through organizing plant } \\
\text { clinic training for its agriculture officers }\end{array}$ \\
\hline
\end{tabular}

Source: Adhikari et al., 2013; Boa \& Harling, 2008; DoAE, 2011; K.C. et al., 2003 
A plant health clinic is a community-based advisory service run by extension workers who are called as plant doctors (Bentley et al., 2007; Danielsen \& Kelly, 2010). The 'plant doctor', is an unofficial title to those extension people who run clinics along with their regular extension work. This concept was developed by CABI to overcome the gaps of plant health extension services in developing countries through providing regular, low-cost plant health services to farmers (Bentley et al., 2011, 2009, 2007). A plant health clinic provides primary healthcare (Danielsen \& Kelly, 2010), a proven concept for humans and animals. Plant clinic was first piloted in Bolivia (Bentley \& Boa, 2004). In 2008, Nepal started to run clinics from Lamjung through an INGO called World Vision International with support of CABI and stood as $9^{\text {th }}$ country to run clinics globally (Boa \& Harling, 2008). In a short time period, this concept was spread significantly and adopted widely. During 2008 to 2011, total number of extension staffs receiving the plant doctors' training course reached to 171 (Adhikari et al., 2013). In 2012 and 2013, additional 86 extension staffs from were trained. These trainees were from different organizations including Department of Agriculture (DOA), Nepal Agriculture Research Council (NARC), Universities, NGO/INGOs, agro-input dealers, farmer's cooperatives and leader farmers.

\section{Profile of plant doctors}

Different studies of has shown the influence of demographic and socio-economic characters on qualitative researches. Therefore, this study has also tried to comprehend profile of the plant doctors. Basic descriptive statistics on some of the major variables is presented in table 2 . Out of total respondents, $86 \%$ were male. The respondents were from 6 different organization types and out of them were from government. The levels of education of the respondent was from primary education to highest degree but greater percentage $(40.3 \%)$ of respondent had achieved bachelor degree. The proportion of plant doctors in each category on years of experience on agriculture extension was found to be distributed consistently between $20-30 \%$ whereas highest number $(42.1 \%)$ of plant doctors have 2-3 years of experience in running clinics. Out of total plant doctors $36 \%$ of them fall in category of participation in 5-10 clinics. 
Table 2. Profile of plant doctors

\begin{tabular}{|c|c|c|c|}
\hline Variables & Value categories & Frequency $(n=114)$ & Percentage \\
\hline \multirow{2}{*}{ Gender of Respondent } & Female & 16 & 14 \\
\hline & Male & 98 & 86 \\
\hline \multirow{6}{*}{ Organization Type } & Farmer's organization & 6 & 5.2 \\
\hline & Government & 56 & 49.1 \\
\hline & International NGO & 14 & 12.3 \\
\hline & Local/National NGO & 22 & 19.3 \\
\hline & University & 11 & 9.6 \\
\hline & Private Sector & 5 & 4.4 \\
\hline \multirow{5}{*}{ Education } & Under SL & 5 & 3.5 \\
\hline & Intermediate & 19 & 17.6 \\
\hline & Bachelor & 45 & 40.3 \\
\hline & Masters & 43 & 36 \\
\hline & PhD & 2 & 2.6 \\
\hline \multirow{4}{*}{$\begin{array}{l}\text { Experience } \\
\text { Extension }\end{array}$} & $<3$ year & 29 & 25.4 \\
\hline & 3-5 year & 35 & 30.7 \\
\hline & $5-10$ yea & 26 & 22.8 \\
\hline & $>10$ yea & 24 & 21.1 \\
\hline \multirow{5}{*}{$\begin{array}{l}\text { Source of information on plant } \\
\text { clinic }\end{array}$} & News & 7 & 6.1 \\
\hline & Official & 19 & 16.7 \\
\hline & Personal & 9 & 7.9 \\
\hline & Training & 73 & 64 \\
\hline & Web/Internet & 6 & 5.3 \\
\hline \multirow{4}{*}{ Experience on plant clinic } & $<1$ Year & 39 & 34.2 \\
\hline & $2-3$ Yea & 48 & 42.1 \\
\hline & 4-5 Year & 20 & 17.6 \\
\hline & $>5$ Year & 7 & 6.1 \\
\hline \multirow{4}{*}{ Number of clinics participated } & $<5$ clinics & 36 & 32.5 \\
\hline & 5-10 clinics & 41 & 36 \\
\hline & $11-20$ clinics & 24 & 21 \\
\hline & $>30$ clinics & 13 & 10.5 \\
\hline
\end{tabular}

\section{SWOT Analysis}

The main purpose of the SWOT analysis was to comprehend what and how the plant doctors themselves perceive regarding the relative strengths, weakness, opportunities and threats of plant clinic operation in Nepal. The finding of the SWOT analysis along the index of importance of the respective statements is presented in table 3 .

It is always very important for any extension service delived should be based on the need and demand of the client. Plant doctors have given highest weightage to plant clinic to be need and demand driven which led to the increased presence of public extension services in rural areas with trained human resources on plant health problems thereby increasing access to extension services among smallholder farmers and adoption of cost effective and eco-friendly production practices.

On the other hand, understanding of plant clinics and its service mechanism is still little understood by private sector service providers. In addition, inadequate resources allocated for clinic operation by government as well as non-government sector is another weakness realized by plant doctors resulting difficulty in regularity of clinic operation. In spite of scope to provide effective and efficient plant health care services, inadequate coordination effort among related institutions is another weakness due to either poor institutionalization or inadequate human resource.

Plant doctors themselves have seen huge opportunity of plant clinics in Nepal because of increasing interest and demand by farmers. Furthermore, there is opportunity of international 
collaboration to design service mechanism which help to increase the productivity in lower cost with adoption of eco-friendly approaches.

In spite of wider scope of plant clinics operation in Nepal, there are some critical threats. There is some possibility of wrong recommendation when the plant doctors have poor or limited knowledge and skill on identifying the problem and unable to endorse appropriate control measures. Furthermore, the inadequate resources allocated in agriculture is always pressurizing to limit the clinic events and thereby questioning the sustainability.

Table 3. SWOT analysis of plast health clinic

\begin{tabular}{|c|c|}
\hline Strengths & Index \\
\hline $\begin{array}{l}\text { Extension services are becoming more need and } \\
\text { demand driven }\end{array}$ & 3.70 \\
\hline $\begin{array}{l}\text { Presence of public extension service system has } \\
\text { increased in rural areas }\end{array}$ & 3.62 \\
\hline $\begin{array}{l}\text { The number of trained manpower in agriculture } \\
\text { extension particularly plant health problems } \\
\text { increased. }\end{array}$ & 3.60 \\
\hline $\begin{array}{l}\text { Farmers knowledge and awareness on plant health } \\
\text { problems has increased }\end{array}$ & 3.55 \\
\hline $\begin{array}{l}\text { Increased access to extension services to larger } \\
\text { number of audience/farmers }\end{array}$ & 3.47 \\
\hline $\begin{array}{l}\text { Knowledge and skill of public and private extension } \\
\text { staffs has increased }\end{array}$ & 3.38 \\
\hline Committed organizations and plant doctors. & 3.23 \\
\hline $\begin{array}{l}\text { Increased and active participation of smallholder } \\
\text { farmers }\end{array}$ & 3.23 \\
\hline $\begin{array}{l}\text { Public-Private Partnership (GO-NGO) in extension } \\
\text { services started }\end{array}$ & 3.19 \\
\hline $\begin{array}{l}\text { Adoption of cost effective and eco-friendly } \\
\text { production practices has enhanced }\end{array}$ & 3.04 \\
\hline
\end{tabular}

\begin{tabular}{l|l|}
\hline Weakness & Index \\
\hline $\begin{array}{l}\text { Limited (and biased) understanding among } \\
\text { agro-vet entrepreneurs }\end{array}$ & 3.79 \\
\hline $\begin{array}{l}\text { Inadequate resource allocation for clinic } \\
\text { operation }\end{array}$ & 3.60 \\
\hline $\begin{array}{l}\text { Irregularity of clinic operation } \\
\text { Inadequate coordinated effort among related }\end{array}$ & 3.34 \\
institutions/organizations & 3.45 \\
\hline $\begin{array}{l}\text { Inadequate support services especially on } \\
\text { diagnosis }\end{array}$ & 3.32 \\
\hline $\begin{array}{l}\text { Poor institutionalization of the clinic concept. } \\
\text { Inadequate personnel thus increased workload } \\
\text { of existing extension staffs }\end{array}$ & 3.17 \\
\hline $\begin{array}{l}\text { Lack of clarity on roles of different } \\
\text { organizations/units and stakeholders }\end{array}$ & 3.15 \\
\hline $\begin{array}{l}\text { Inadequate horizontal and vertical linkage and } \\
\text { coordination }\end{array}$ & 2.17 \\
\hline
\end{tabular}

\begin{tabular}{|l|l|}
\hline Opportunities & Index \\
\hline $\begin{array}{l}\text { Increasing interest and demand for clinics by } \\
\text { farmers }\end{array}$ & 3.66 \\
\hline $\begin{array}{l}\text { International cooperation with different } \\
\text { organizations }\end{array}$ & 3.53 \\
\hline $\begin{array}{l}\text { Increasing productivity along with lower cost of } \\
\text { production }\end{array}$ & 3.49 \\
\hline \begin{tabular}{l} 
Integration of clinics concept in public extension \\
\hline $\begin{array}{l}\text { Personal counseling to individual farmers for eco- } \\
\text { friendly approaches }\end{array}$
\end{tabular} & 3.44 \\
\hline $\begin{array}{l}\text { Ownership by Government is gradually } \\
\text { increasing, }\end{array}$ & 3.32 \\
\hline $\begin{array}{l}\text { InterestandCommitment fromdiverseorganizations } \\
\text { (GOs, NGOs INGOs and CBOs) }\end{array}$ & 3.02 \\
\hline Clinics run by community-based organizations & 2.81 \\
\hline
\end{tabular}

\begin{tabular}{l|l|} 
Threats & Index \\
\hline $\begin{array}{l}\text { Recommendations of low skilled plant doctors } \\
\text { could be misleading. }\end{array}$ & 3.79 \\
\hline $\begin{array}{l}\text { Inadequate budget and resources allocated in } \\
\text { agriculture sector by government and non- } \\
\text { government sectors }\end{array}$ & 3.64 \\
\hline $\begin{array}{l}\text { Insufficient donor commitment to support } \\
\text { plant clinic operation especially for small } \\
\text { NGOs and CBOs. }\end{array}$ & 3.23 \\
\hline Sustainability of plant clinic operations. & 3.21 \\
\hline $\begin{array}{l}\text { Increasing priority for private extension } \\
\text { services }\end{array}$ & 2.66 \\
\hline $\begin{array}{l}\text { Conflict of interest at personal and } \\
\text { organizational level. }\end{array}$ & 2.64 \\
\hline
\end{tabular}




\section{CONCLUSION}

Plant health clinic was invented to overcome the gap in agriculture extension through providing primary health care services to the smallholder farmers to tackle a wide range of plant health problems in their crops. In 2003, it was first piloted in Bolivia which is gradually replicated to other countries and introduced in Nepal only 2008. Since then, Government of Nepal and other different NGOs are running plant clinics or helping others to run clinics.

This SWOT analysis clearly spells the scope of plant clinics to fulfill the gap between farmers need and existing services provided by ASCs and DADOs. The number and the passion of farmers visiting the clinics signify beauty of this approach. On the other hand, the plant doctors themselves are found to be happy what they have done and optimistic in expanding the scope of this approach. With introduction of plant clinics, even the plant doctors have realized that the agriculture extension system now becoming more need based and demand driven by the real clients which has helped to realize the existence of public extension service among rural farmers.

The rapid expansion of clinics has been possible due to contributions from individuals in many organizations who saw clinics as an effective way to provide advisory services to farmers. This piece of research highlights current state of strengths, weakness, opportunities and threats of plant clinics to overcome gaps in the plant health services system in Nepal, but still more systematic and thorough research is needed to assess the impact on farm level. Furthermore, strategic interventions and smooth cooperation are essential to promote community based regular clinic operation along with functional linkages among stakeholders. Importantly, integration of clinic operation into the core agricultural extension program with efficient database management and use in the further planning process is essential.

\section{REFERENCE CITED}

Adhikari, R., Regmi, P., Boa, E., GC, Y., \& Thapa, R. 2013. Innovation in plant health extension services: the case of Plant Clinics in Nepal. ECONOMIA AGRO-ALIMENTARE, 15(1), $235-245$.

Alonge, A. J. 2006. Bringing stakeholders into agricultural extension reform agenda: a participatory swot analysis of the Trinidad national agricultural extension service. In International Teamwork in Agricultural and Extensioin Education (pp. 12-23). Clearwater Beach, Florida: Associaiton of International Agricultural and Extension Education. Retrieved from https://www.aiaee.org/ attachments/article/906/012.pdf

Anandajayasekeram, P., Davis, K. E., \& Workneh, S. 2007. Farmer field school: An alternative to existing extension system? Experience from Eastern and Southern Africa. Journal of International Agricultural and Extension Education, 14(1), 81-93. http://doi.org/10.5191/ jiaee.2007.14107

Atreya, K. 2005. Health cost of pesticide use in a vegetable growing area, central mid hills, Nepal. Himalayan Journal of Sciences, 3(5), 81-84. http://doi.org/10.3126/hjs.v3i5.466

Avison, D., \& Fitzgerald, G. 2006. INFORMATION SYSTEMS DEVELOPMENT (4th edition). London: McGraw-Hill Education.

Bentley, J. W., \& Boa, E. (2004). Community plant health clinics, an original concept for agriculture and farm families. UK: Global Plant Clinic-CABI.

Bentley, J. W., Boa, E., Almendras, F., Franco, P., Antezana, O., Diaz, O., Villarroel, J. 2011. How farmers benefit from plant clinics: an impact study in Bolivia. International Journal of Agricultural Sustainability, 9(3), 393-408. http://doi.org/10.1080/14735903.2011.583482

Bentley, J. W., Boa, E., Danielsen, S., Franco, P., Antezana, O., Villarroel, B., Colque, S. 2009. Plant 
health clinics in Bolivia 2000-2009: opeation and preliminary results. Food Security, 1(3), 371-386.

Bentley, J. W., Boa, E., Danielsen, S., \& Zakaria, A. K. M. (2007). Plant clinics for healthy crops. LEISA Magazine, 23(4), 16-17.

Boa, E. 2009. How the Global Plant Clinic began. Outlooks on Pest Management, 20(3), 112-116.

Boa, E., \& Harling, R. 2008. Starting plant health clinics in Nepal (p. 23). UK: Global Plant ClinicCABI.

Boone, H. N., \& Boone, D. A. 2012. Analyzing Likert Data. The Journal of Extension (JOE), 50(2). Retrieved from http://www.joe.org/joe/2012april/tt2.php

Chipeta, S. 2006. Demand driven agricultural advisory services. (D. Pesche, T. Zellweger, \& I. Christoplos, Eds.). Germany: NEUCHATEL Group.

Danielsen, S., \& Kelly, P. 2010. A novel approach to quality assessment of plant health clinics. International Journal of Agricultural Sustainability, 8(4), 257-269. http://doi.org/10.3763/ ijas.2010.0494

DoAE. 2011. Directorate of Agricultural Extension. Retrieved from http://www.agriextension.gov. np/eng/introduction.php

European Commission. (2005). Monitoring of Pesticides Residues in Products of Plant Origin in the European Union, Norway, Iceland and Liechtenstein. Commission of the European Communities.

Hanyani-Mlambo, B. T. 2002. Strengthening the pluralistic agricultural extension system: a Zimbabwean case study. Integrated Support to Sustainable Development and Food Security Programme /Food and Agriculture Organization of United Nations.

Humphrey, A. S. 2005. SWOT Analysis. Retrieved from http://www.businessballs.com/ swotanalysisfreetemplate.htm

K.C., G. K., Pradhan, D., Upadhyay, B. P., \& Upadhyay, S. 2003. Sharing country agricultural extension experiences, challenges and opportunities. Presented at the Regional workshop on operationalizing agricultural extension reforms in South Asia, New Delhi, India. Retrieved from http://info.worldbank.org/etools/docs/library/51025/ZipAgExtension1/ag_extension1/ Materials/Plenary/Nepal.pdf

Kroschel, J., Alcazar, J., \& Poma, P. 2009. Potential of plastic barriers to control Andean potato weevil Premnotrypes suturicallus Kuschel. Crop Protection, 28(6), 466-476. http://doi.org/10.1016/j. cropro.2009.01.008

Landon, L. C. 1996. Participatory rural appraisal concepts applied to agricultural extension : A case study in Sumatra. Quarterly Bulletin of the International Association of Agricultural Information Specialists, 41(1), 100-103.

Likert, R. 1932. A technique for the measurement of attitudes. Archives of Psychology, 22 140, 55.

Mlambo, H. 2002. Strengthening the pluralistic agricultural extension system: a Zimbabwean case study. Food and Agricutlure Organization of the United Nations.

Oerke, E. 2006. Crop losses to pests. The Journal of Agricultural Science, 144(01), 31-43. http://doi. org/10.1017/S0021859605005708

Piggin, C. 2003. Working group SWOT analysis on agriculture development in East Timor. In ACIAR Proceedings (pp. 159-162). East Timor.

Plantwise. 2011. Plant Clinics. Retrieved December 20, 2011, from www.plantwise.org/default. aspx ? site $=234 \&$ page $=4268$

Purcell, D. L., \& Anderson, J. R. 1997. Agricultural extension and research: achievements and problems in national systems. Washington, D.C .: World Bank. Retrieved from http://www. 
cabdirect.org/abstracts/19996776883.html;jsessionid=B38029369CA738F07DEF5D1795DC 82CB?gitCommit=4.13.20-5-ga6ad01a

Shahraki, E., \& Ebrahimzadeh, A. 2013. The Specialists' Strategic Analysis On Development of Broiler Poultry Industry In Sistan Region. International Journal of Agriculture and Crop Sciences., 6(14), 1032-1039.

Shrestha, P. L., \& Neupane, F. P. 2002. Socio-economic context on pesticide use in Nepal. Landschaftsökologie Und Umweltforschung, 38, 205-223.

Thapa, T. B. 2010. Agricultural Extension Services Delivery System in Nepal. Food and Agriculture Organization of Uniated Nations, Kathmandu, Nepal. Retrieved from ftp://ftp.fao.org/TC/ CPF/Country\%20NMTPF/Nepal/AgExtServDelSysNepal.pdf

Umali, D. L., \& Schwartz, L. 1994. Public and private agricultural extension: beyond traditional frontiers. World Bank Discussion Paper, 236.

Weihrich, H. 1982. The TOWS matrix - A tool for situational analysis. Long Range Planning, 15(2), 54-66. http://doi.org/10.1016/0024-6301(82)90120-0

Zack, M. H. 1999. Developing a Knowledge Strategy. California Management Review, 41(3), 125145. 